\title{
A CASE OF GYRATE ATROPHY OF THE CHOROID AND RETINA WITH HYPOGENITALISM
}

BY

\section{E. Cunningham DaX}

GyRATE atrophy of the choroid and retina is a very rare condition which was first described by Cutler in 1894 . It is said to be one of the abiotrophies and to be related to retinitis pigmentosa. The evidence upon which this is based is that the symptoms of night blindness, contracting visual fields and progression to blindness are common to both conditions. Moreover in gyrate atrophy there is some disturbance of the retinal pigment, and abnormalities are often found in the papilla and retinal vessels similar to those observed in pigmentary retinal degeneration. In gyrate atrophy myopia is said to be constant, in retinitis pigmentosa it is not uncommon, and cataract is frequently found in both conditions. A pedigree has been described by Bohm (1919) in which both abnormalities have been found, and Zorn (1920) and Beckershaus (1926) have seen retinitis pigmentosa and conditions somewhat similar to gyrate atrophy in other families.

In its typical form gyrate atrophy may be recognised by an atrophic area around the disc, surrounded by a zone of normal choroid in which further atrophic patches are again seen towards the periphery. The atrophic portions are lobulated to form bays projecting into the normal choroid. Pigmentation is frequently seen at the edges of the bays as well as in discrete deposits in front of the retinal vessels. There has been some variability in the cases recorded and Sorsby (1939) has classified them into three groups whose names sufficiently illustrate their characteristics. (a) The garland type. (b) The multiple colobomatous type. (c) The disseminated pigmentary type. A case of the first type under Mr. Arnold Sorsby's care has no hypogenitalism and the glucose tolerance curve is normal. The cases published were reviewed by Usher (1935).

\section{Case Record}

He was born in 1860 , admitted to a mental hospital in 1927 , and transferred to Leavesden Hospital in 1932. His wife was interviewed soon after his admission, but she appeared to have a poor memory, rambled in her speech and showed signs of senile dementia. She was quite incapable of giving any family history.

Past history.-He was married in 1887, became fat in 1907, and in 1913 lost the sight of his left eye through the blow of a potato thrown at him whilst working in Covent Garden. He developed 
a cataract in his right eye and later became blind. It was said that he had never shaved.

In the notes made on his admission in 1927 it was stated that he had bronchitis and emphysema and a systolic blood pressure

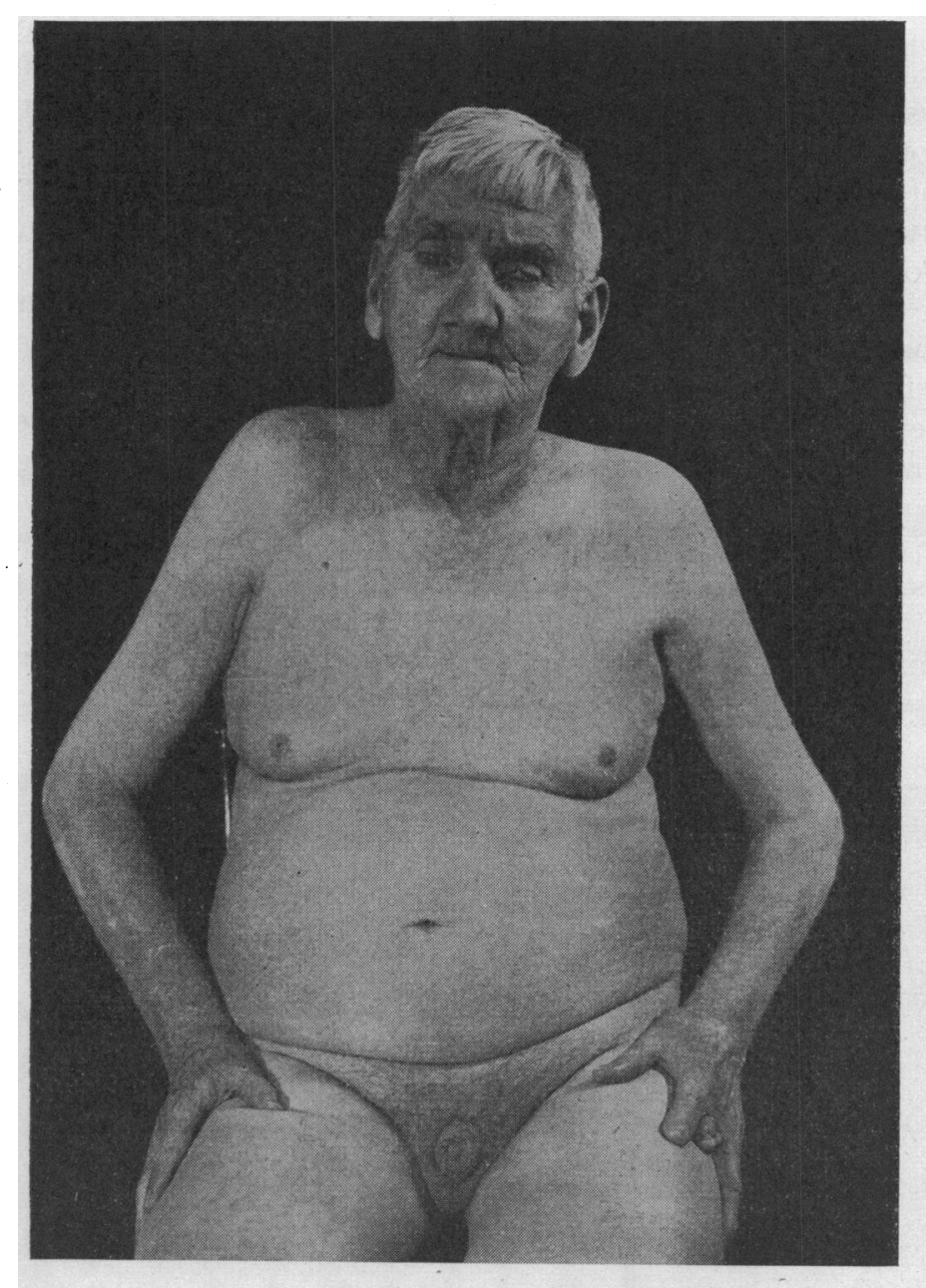

of $140 \mathrm{~mm}$. $\mathrm{Hg}$. The nervous system was normal. He had a female appearance with scanty hair on his pubis, developed breasts and small testes without sensation. He had a rotatory nystagmus, and perception of light in the right eye. The left eye had a central nebula of the cornea and a traumatic cataract. An iridectomy had been performed. His Wassermann reaction was 
negative. His weight was eleven stones. During the years he was there he fractured a femur and both wrists. He had delusions that his food was poisoned and that his wife was unfaithful to him.

Present condition. Mental.- He is quiet when undisturbed, but needs to be carefully managed or he becomes irritable and even violent. He is very deluded even over the every day incidents of his life and mistaken in identities. He is euphoric and never lost for an answer, even if his memory should fail him.

Eyes.-The left cornea is opaque, bluish-white, and no further view of the eye is possible. In the right fundus there is a large area of choroido-retinal atrophy surrounding the normal disc and continued along the superior and inferior temporal vessels to meet at a point peripheral to the macula, thus enclosing a normal area in the macular region, and another smaller area between the inferior temporal artery and vein. The margins of the atrophic areas form lobulated bays projecting into the normal choroid. Further out in the periphery other atrophic areas with pigmented margins can just be made out. Some marginal pigmentation to the central atrophic area is not shown in the drawing. The arteries are rather small, the pigment lies in front of the retinal vessels. The refraction is emmetropic. He appears to be practically blind in this eye, though he has some perception of light. The pupil dilates very little with atropine as the result of an old irido-cyclitis due to a mild sympathetic ophthalmitis contracted

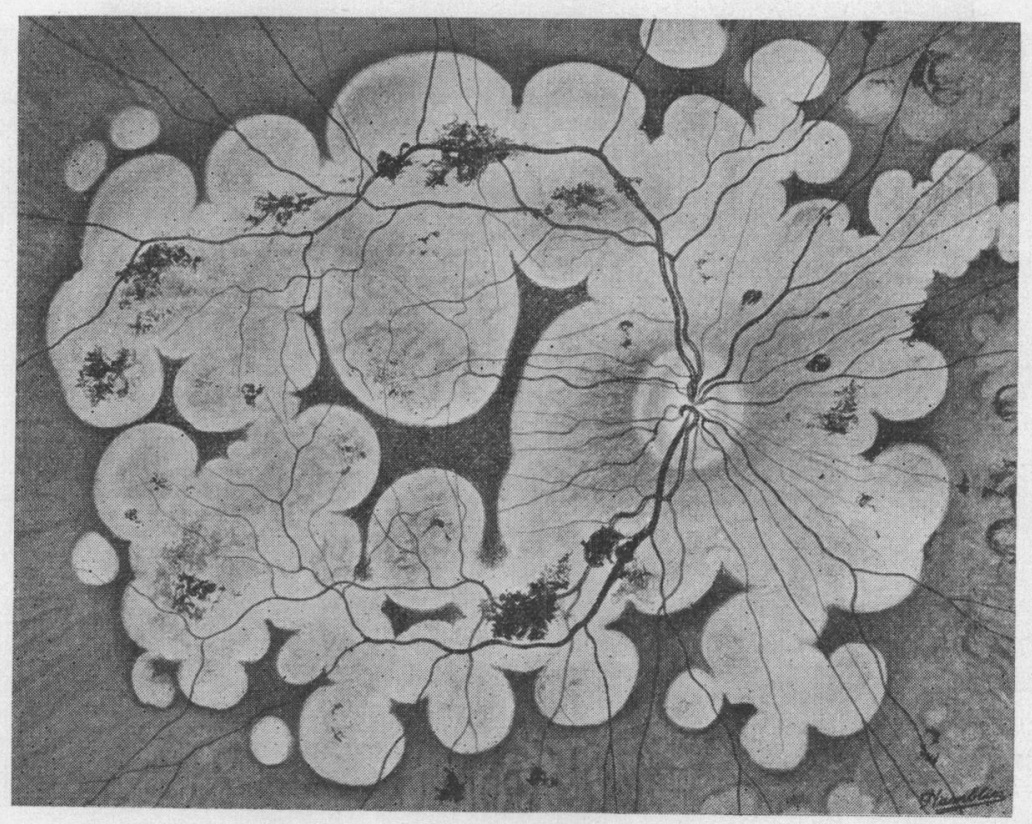


at the time when the other eye was injured. The right iris is yellow-brown in colour.

General.-There is much obesity of the chest and abdomen but the limbs are normal. He has arthritis particularly in the right knee. The skin is rather dry, the hair white. Blood pressure 205/105. Marked thickening and tortuosity of the brachial arteries. Slight enlargement of the heart, a soft apical systolic murmur and signs of myocardial degeneration. Pulse 60-70/minute. He has bronchitis and emphysema. Thyroid normal. Nothing abnormal in his abdomen. Reflexes sluggish. No fits, sleeps normally and does not complain of headaches.

There is no axillary hair and that on the pubis is of female distribution. He grows no beard, and has large breasts. His face looks like that of an old woman. His penis is small, and his testes though little larger than peas are in his scrotum. He was married; it is said that his wife told a nurse that he was not impotent. He said that he had no children but added "That wasn't my fault."

\section{Investigations}

Craniometry._- Inner canthus distance $3.6 \mathrm{cms}$. Mean palpebral fissure width $2.65 \mathrm{cms}$. Maximum breadth $14.4 \mathrm{cms}$. Maximum length $18.6 \mathrm{cms}$. Cephalic index 77. Height $12.7 \mathrm{cms}$. Circumference $54.0 \mathrm{cms}$. Capacity $1316 \mathrm{c} . \mathrm{cs}$. The capacity is less than normal but the head is of the usual shape without any sign of hydrocephalus as shown by the measurements.

Skeleton.-Height 67 ins., span 67 ins.; Pubis-vertex, 32 ins.; Pubis-feet, 35 ins. The legs are rather long and the trunk is short as compared to the height and span.

Weight.-Now 9 st. 4 lbs., but he is gradually losing weight.

Temperature.-Normal for ten days taken four hourly by the mouth. Hyperthermia has been found in some cases of retinitis pigmentosa, conditions related to the Laurence-Moon-Biedl syndrome and also in obesity associated with disturbance in watersalt metabolism.

Blood.-Wassermann reaction negative. Cholesterol $168 \mathrm{mgm}$. per cent. (normal).

Glucose tolerance curve.

1935.

1938.

0 hrs. $\quad . . \quad 101 \mathrm{mgm}$. per cent. $94 \mathrm{mgm}$. per cent.

$\frac{1}{2}$ hrs. ... $145 \mathrm{mgm}$. per cent. $153 \mathrm{mgm}$. per cent.

1 hrs. $\quad . . \quad 138 \mathrm{mgm}$. per cent. $260 \mathrm{mgm}$. per cent.

$1 \frac{1}{2}$ hrs. $\quad . . \quad 164 \mathrm{mgm}$. per cent. $218 \mathrm{mgm}$. per cent.

2 hrs. ... $140 \mathrm{mgm}$. per cent. $142 \mathrm{mgm}$. per cent.

Though the curve in 1935 was within normal limits, that found more recently shows a diminished tolerance, as is sometimes seen in cases of hypogenitalism and obesity. 
Urine.-Yellow. Acid. S.G. 1024. No abnormal constituents. A few organisms and leucocytes and calcium oxalate crystals in the deposit.

Water-salt metabolism.-After four days feeding on a diet with low chloride content.

$\begin{array}{ccrr} & & \text { Urine Volume. } & \text { Sodium } \text { Chloride. } \\ \text { 5th day } & \ldots & 1250 \text { c.cs. } & 3.75 \text { gms. } \\ \text { 6th day } & \ldots & 783 \text { c.cs. } & 3.45 \text { gms. } \\ \text { 7th day } & \ldots & 1015 \text { c.cs. } & 4.42 \text { gms. } \\ \text { 8th day } & \ldots & 1148 \text { c.cs. } & 4.82 \text { gms. } \\ \text { 9th day } & \ldots & 1350 \text { c.cs. } & 12.69 \mathrm{gms} . \\ \text { 10th day } & \ldots & 1110 \text { c.cs. } & 7.88 \text { gms. }\end{array}$

10 grams of salt were given on the ninth morning. There is no chloride retention and a normal increase in urinary volume after sodium chloride was given.

Urine dilution test.

$$
\begin{aligned}
& \begin{array}{llll}
7.40 \text { a.m. } & \ldots & \ldots & 440 \text { c.cs. }
\end{array} \\
& 9 \text { a.m. } \quad \ldots . \quad \ldots \quad 370 \text { c.cs. } \\
& \begin{array}{rrrrr}
10.10 & \text { a.m. } & \ldots & \ldots & 50 \text { c.cs. } \\
11 & \text { a.m. } & \ldots & \ldots & 40 \text { c.cs. }
\end{array}
\end{aligned}
$$

1000 c.cs. of water were given between 6 and $6.30 \mathrm{a} . \mathrm{m}$. There is a diminished rate of urinary secretion, the output is small and there is a delay in reaching the maximum rate of secretion compared with controls. On the other hand not much significance can be attached to these results in view of the patient's age, arteries and blood pressure.

Melanosome dispersion was not observed with several specimens of urine or by a sample of blood.

$$
\begin{array}{llcc} 
& & \multicolumn{3}{c}{\text { Vitamin } C \text { excretion on a constant diet. }} \\
\text { 1st day } & \ldots & \ldots & 5 \cdot 56 \mathrm{mgm} \text {. ascorbic acid } \\
\text { 2nd day } & \ldots & \ldots & 7 \cdot 14 \mathrm{mgm} \text {. ascorbic acid } \\
\text { 3rd day } & \ldots & \ldots & 8 \cdot 14 \mathrm{mgm} \text {. ascorbic acid }
\end{array}
$$

300 mgms. of ascorbic acid were given on the 3rd, 4th, 5th and 6 th mornings. In the next 24 hours he passed 1130 c.cs. of urine, but only excreted $13.15 \mathrm{mgms}$. of Vitamin C. Three controls excreted 150,195, and $220 \mathrm{mgms}$. respectively. It has been suggested that the Vitamin $\mathrm{C}$ in the retina may be destroyed in certain diseases leaving the cells prone to degenerative changes. A normal Vitamin $\mathrm{C}$ excretion in this case would have produced some evidence against this hypothesis, but the observed deficiency is of no significance in view of his age. (Gander and Niederberger, 1936.) 


\section{Discussion}

This case of gyrate atrophy of the choroid and retina is of the multiple colobomatous type. It is remarkable for the fact that there is no myopia and that the condition appears to have been first noticed late in life. The hypogenitalism is interesting especially as it is accompanied by a diminished glucose tolerance and an obesity which is said to have appeared suddenly in middle age.

The failure of the urine and a specimen of blood to produce melanosome dispersion in the frog is of interest. In 1938 the blood and urine in cases of retinitis pigmentosa was shown by the writer to contain a substance which would " expand" the melanophores of the frog. Riddell (1939) confirmed this finding in cases of retinitis pigmentosa, but the urine of a patient with choroideremia did not affect the colour of the frogs. In view of the supposed relationship between the three conditions these experiments may be of importance.

There is nothing in this history or the investigations to add support to the relationship between gyrate atrophy of the choroid and retina and retinitis pigmentosa.

\section{Summary}

A case of gyrate atrophy of the choroid and retina is described.

The points of interest are an absence of myopia, the recognition of the condition late in life and the associated hypogenitalism and obesity.

The urine failed to disperse the melanosomes of the frog.

I am very grateful to Mr. Arnold Sorsby and Dr. R. M. Stewart for their kind assistance.

\section{REFERENCES}

Beckershaus, F. (1926).-Klin. Monatsbl. $f$. Augenheilk., Vol. LXXVI, p. 384. Вонм, F. M. (1919).-Ibid., Vol. LXIII, p. 381.

CUtLer, C. W. (1894).-Arch.f. Augenheilk., Vol. XXX, p. 117.

DAX, E. C. (1938).-Brit.Jl. Ophthal., Vol. XXII, p. 345.

GANDER, J. and NiEDERBERGER, W. (1936).-Münch. med. Wochenschr., Vol. XXXIV, p. 1386.

RIDDELL, W. J. B. (1939).-Trans. Ophthal. Soc. U.K., Vol. LIX, (i), p. 275.

Sorsby, A. (1939).-Proc. Roy. Soc. Med., Vol. XXXII, (i), p. 359.

USHER, C. H. (1935).-Trans. Ophthal. Soc. U.K., Vol. LV, p. 164.

ZORN, B. (1919).-Arch.f. Ophthal., Vol. LXIII, p. 381. 